ductive academics from Vietnam are studying or working outside their home country. For instance, nearly roo percent of the brightest high school graduates from the best high schools in Hanoi and Ho Chi Minh City go abroad for undergraduate education. Similarly, most of the Vietnamese students who achieved medals in the International Mathematical Olympiads are working as academics in developed countries.

English as a Language Barrier. The fact that English is not the official language of instruction and publication in many countries in the region is another obstacle to attracting international students and to participating in the broader scientific community. With the exception of Singapore, the Philippines, and Thailand, most universities in the region offer very few courses in English. This is one reason why few international students come to those institutions for exchange programs, let alone a degree. If the effort to provide more courses in English at an acceptable cost is not successful, it is foreseeable that universities where English is not a language of instruction will not become attractive places for a large pool of international students.

It is crucial that the countries of Southeast Asia recognize the challenges described in this article. Clearly, they should frame higher education policies in order to overcome the challenges to reduce negative impacts and improve quality and educational effectiveness. This is a way to improve their level of higher education and increase their contributions to social development.

\section{France Debates International Student Fees}

\section{Ariane de Gayardon}

Ariane de Gayardon is a PhD candidate in Higher Education at Boston College. She is also a graduate research assistant at the Center for International Higher Education. E-mail: ariane.de.gayardon@gmail.com.

W ith 4 million students studying abroad in 20I2, student mobility has become one of the most prominent features of the internationalization of higher education. But host countries receiving an ever-increasing number of international students are starting to think over their funding strategy. In an age of global austerity, it is legitimate to question whether international students' education should be as subsidized as domestic students' education.
This question was under scrutiny in France during the first half of 20I5, as a report by France Stratégie-a think tank working for the prime minister-suggested the introduction of international tuition fees. France is not the first country to face this debate and will not be the last, but it takes special significance in the third most attractive country in the world and in a country where half the international students come from Africa.

\section{Welfare States}

European welfare states have proven particularly vulnerable to the debate around the financing of higher education for non-domestic students, as they subsidize heavily higher education, which is conceived as a right. In a time of financial hardship for higher education globally, the welfare states are questioning whether they should continue to accept international students under these lenient financial conditions. The fact that such debates have been omnipresent in the Nordic countries, the archetypes of welfare states, in the past decade shows how prevalent this question has become. Denmark and Sweden now charge tuition fees to international students, and Finland will likely start doing so in 2016 despite mixed reviews of the trial period and resistance from student unions.

\section{The State of French Higher Education}

France is without doubt a welfare state, with a very lowtuition higher education system. In 20I4-20I5, the tuition fees were at about US\$2 IO annually for undergraduate students-domestic or foreign. Indeed, according to OECD, the French government was funding 80.8 percent of public higher education expenditures in 20II. It was estimated that the government funding of tertiary education exceeded US\$12,500 per student per year, up from US\$7,700 in the I980s. This trend parallels a continuous increase in the number of students. It is in this context, unsurprisingly, that the question of who should be subsidized arose.

In 2015 , a report entitled Investing in the Internationalization of Higher Education was published by the French Prime Minister's think tank. It suggested the introduction of tuition fees covering the full cost of higher education for international students. The fund thus saved would be used to foster the internationalization of universities. But the French context includes specificities that make this debate particularly compelling.

\section{Attractive to Whom?}

France is a unique country because of the position it holds as a host country for mobile students. It was ranked the third most attractive country by UNESCO in 20I2, drawing as much as 7 percent of the 4 million international students. 
Interestingly, the ranking is dominated by countries that charge international students high tuition fees-including the United States, the United Kingdom, and Australia.

The issue of international student fees in France sparked acute debate at least in part because of the origin of its students. Nearly half of the international students studying in France come from Africa, a heritage from France's colonial past. Morocco, Algeria, Tunisia, Senegal, and Cameroon are in the top Io countries of origin. It is very unlikely that these students can afford more than US\$I2,500 of tuition fees. Actually, in the present circumstances-i.e., with very low tuition-82 percent of international students in France declared in a survey that studying in France constitutes a financial strain for them and their families. In these conditions, it is impossible to contemplate such an increase in tuition fee without considering the consequences for these students who want and need to get access to a good higher education system. Additionally, the question of the public good needs to be raised, as France is currently helping countries that are in less fortunate economic conditions, by providing them with the skilled labor that is essential in today's economy.

\section{This question was under scrutiny in France during the first half of 2015, as a report by France Stratégie-a think tank working for the prime minister-sug- gested the introduction of international tuition fees.}

From France's point of view, however, the trade-off is in the quantity and diversity of international students in the system. There is no question that an increase in international tuition fees would have an impact on the number of mobile students coming to France. The 2015 report forecasts a 40 percent decrease, a number that will be hard to gain back. Replacing the international students that will be put off by tuition fees would indeed be extremely difficult, as France does not have the capacity to attract the students that can and are ready to pay-especially when one considers the language barrier and the competition of the United States, the United Kingdom, and Australia among others.

Last but not least, this question needs to be properly examined economically. In 20I4, economic benefits from the presence of international students in France were estimated at nearly US\$5 billion with a positive balance of US\$I.6 billion once the cost of tuition was removed. This far exceeds the US\$930 million the 2015 report estimates would be saved from moving to full cost tuition fees. The economic benefits of having international students participate in the economy might very well be worth the investment in their education.

\section{CONCLUSION}

In July 20I5, the French government put an end to the debate about international tuition fees by stating that international students will continue to pay the same tuition fees as domestic and European ones. But the debate itself opened the door to the possibility of establishing higher tuition fees for international students in the future. Finland, for instance, resisted the trend for a few years but is now set to introduce such fees in September 20I6. When the debate resurfaces, France will once again need to consider the role of international students in the system, but also its role as a developed nation in educating foreign students. Therefore, the debate should not stop at mere economic arguments, but also focus on the diversity in the system, the global and national public good, and even foreign affairs.

\section{UK Teaching Quality Under the Microscope: What are the Drivers?}

\section{ROBIN MiddLehURST}

Robin Middlehurst is external policy adviser and professor at Kingston University London, UK. E-mail: r.middlehurst@kingston.ac.uk.

$T$ The UK higher education system is typically rated highly in relation to the quality of teaching, according to different metrics. In the 2015 national Guardian league table, for example, student satisfaction with teaching across II9 institutions responding to the survey ranged from 77.6 percent to 93.3 percent, while in the most recent National Student Survey (20I5), the range of overall student satisfaction across 156 responding institutions was between 74 percent and 98 percent. National performance indicators also demonstrate that the United Kingdom (overall) is facilitating access to higher education for under-represented groups, is focusing on supporting student progression and educational attainment, and has strong success in the employment of its graduates. 